\title{
STUDIES ON A BLOOM-FORMING BLUE-GREEN ALGA, Anabaena flos-aquae IN THE WASCANA LAKE IN REGINA
}

H.E. MANN, Biology Department, Sir Wilfred Grenfell College, Memorial University of Newfoundland, Corner Brook, NF A2H 6P9 and M.V.S. RAJU, Biology Department, University of Regina, Regina, SK S4S 0A2

Anabaena forms extensive algal blooms in the Wascana Lake of the Qu'Appelle river system in Regina in spring and summer. In late May and June when the lake water begins to warm up, the overwintering cell-type, the akinete, begins to divide in the lake bottom to produce tangled or flexuose masses of filaments (Fig. 1A, B). Air gets trapped between the filaments making the mass buoyant. It migrates to the surface or subsurface regions of the lake in dense masses. Within the individual cells of a filament also gas vacuoles develop which make the flexuose masses buoyant forming an algal bloom.

Algal blooms also called "water blooms" occur throughout the world. Algal bloom formation in lakes is a natural phenomenon in the ecosystem of lakes, especially in shallow saline lakes, of western Canada. In lakes of Saskatchewan many environmental factors, especially total dissolved chemicals, contribute to the formation of algal blooms. ${ }^{7}$ Sewage effluents and farmland and feedlot runoff may increase the phosophorous and nitrates, which stimulate abundant production of algal blooms in lakes. Intense radiation of the sun, common on the prairies, can help concentrate the available total solid contents of lakes encouraging algal blooms.

Most members that form blooms in lakes are the blue-green algae belonging to the division Prokaryota. ${ }^{1,8,9,18}$ The most common genera in lakes of western Canada are Anabaena, Aphanizomenon and Microcystis. ${ }^{5,6,12,13}$ They are ubiquitously distributed in the saline lakes of the world. These blue-greens, which presumably appeared about 3.5 billion years ago in the Precambrian, still retain very similar morphological features. ${ }^{14,15}$ It is important to recognize that they have survived so long without sexual reproduction, indicating the tenacity and recalcitrant nature of their cell structure and the mode of reproduction.

The algae that are known to form abundant blooms reproduce asexually. ${ }^{9,10,17}$ One of the mechanisms is their reproduction by akinetes and this is especially true of the algae that form blooms in Wascana Lake. The remarkable ability of akinetes to germinate simultaneously may be the fundamental reason for uniform and sudden appearance of algal blooms in lakes. 


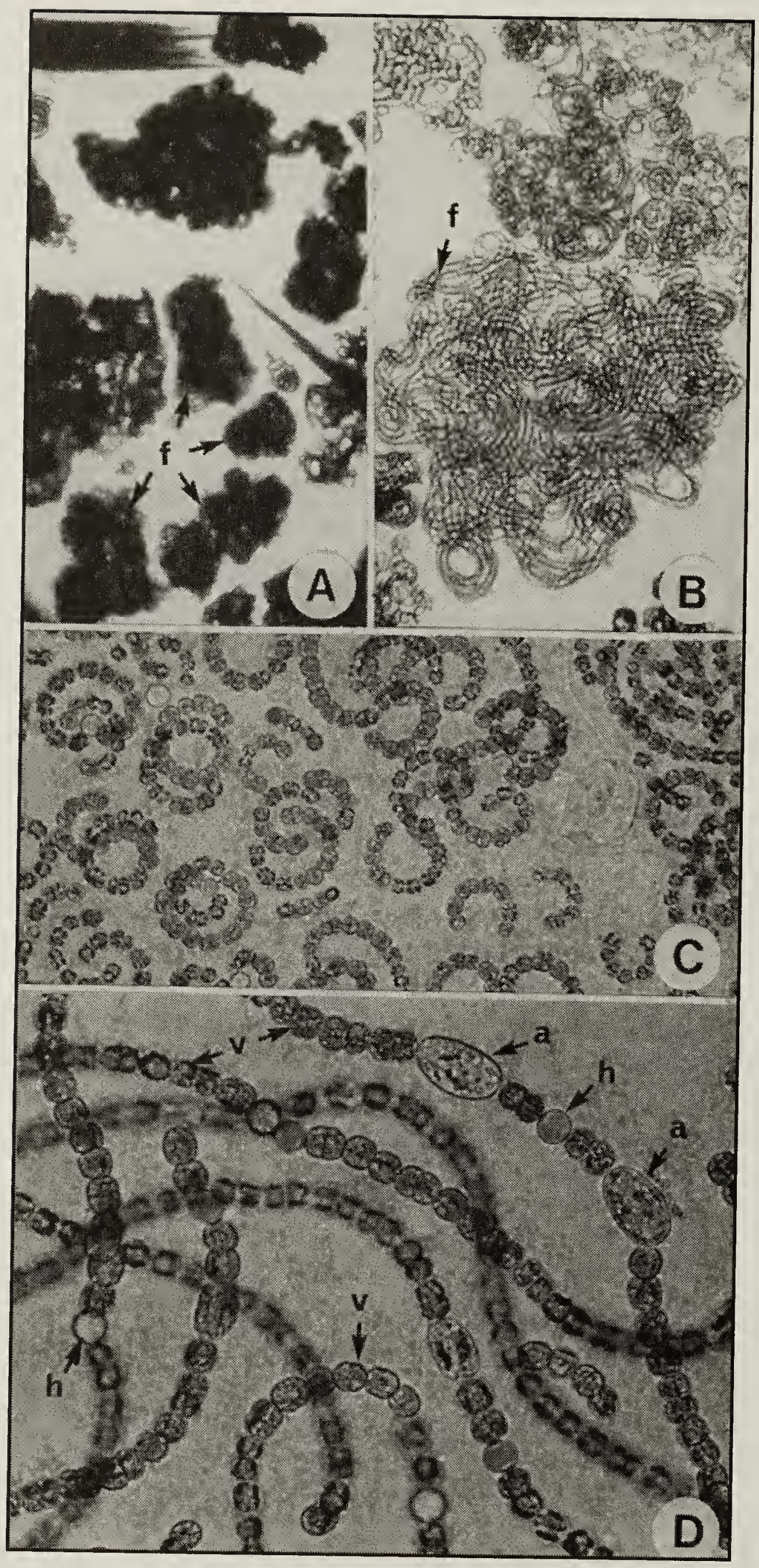

Figure 1. Morphology of filaments of Anabaena flos-aquae (Lyngb.) De. Brébisson collected from the Wascana Lake. A. Clumps of flexuose (f) filaments in early spring. $x$ 120. B. Enlarged view of a flexuose (f) mass to show highly tangled filaments. $x$ 140. C. Enlarged view of short filaments of the alga in summer. $\times 800$. $D$. Enlarged view of unbranched filaments containing vegetative or somatic cells (v), akinetes (a) and heterocysts (h). $\times 1200$. 


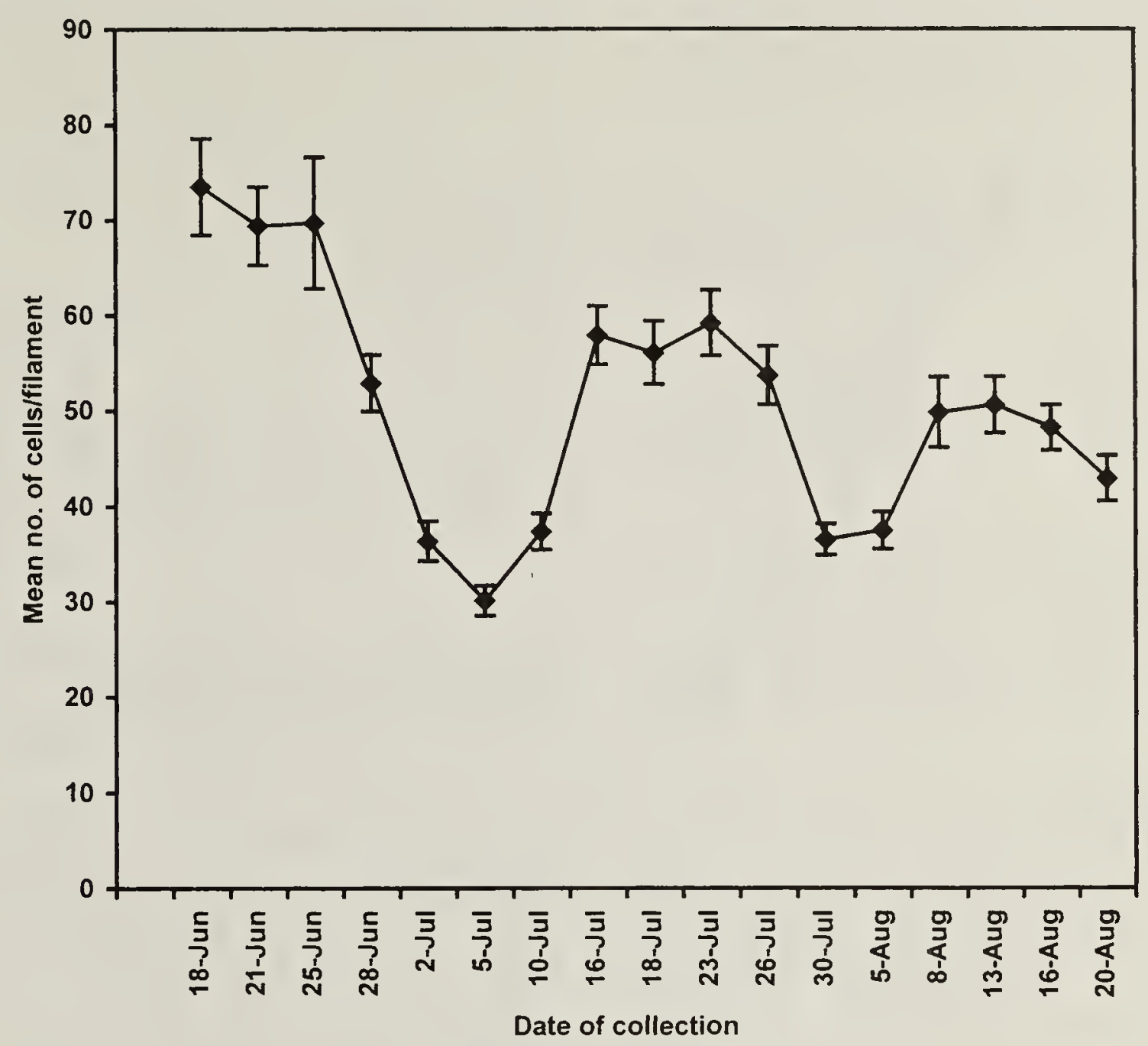

Figure 2. Changes in the number of cells per filament of Anabaena flos-aquae during the growing season in the Wascana Lake. (Standard errors are indicated)

Although general observations on algal blooms in Wascana Lake have been made for many years, the data reported here were obtained during the summers of 1974 and $1984 . .^{10-12}$ During algal bloom at Wascana Lake, the alga Anabaena shows many morphological changes which are reported here (Fig. 1). The masses of Anabaena contain tangled unbranched filaments. These filaments elongate by cell division and the number of cells per filament peaks early in the growing season and decreases progressively by fragmentation until about the first week of July (Fig. 2). In about mid-July the filaments elongate slightly by cell division and subsequently, the filament length remains about the same until the end of the season (Fig. 2). If the environmental conditions remain stable and without strong winds, the filaments may continue to elongate. During the latter part of the summer the individual filaments are also short due to fragmentation (Figs. 1C, 2).

The filaments of Anabaena contain three distinct cell types that can easily be identified and studied under a compound microscope, the vegetative cells, heterocysts and akinetes (Fig. 1D). The vegetative cells (Fig. 1D) contain photosynthetic pigments and other cell inclusions that aid in cell growth and reproduction. The heterocysts (Fig. D) contain a variety of enzymes that help cell functions, including the unique fixing of elemental nitrogen from the atmosphere to form nitrogen compounds transported to other cells. ${ }^{3,16}$ They also form the sites where the filaments separate to form shorter filaments. The akinete is a 


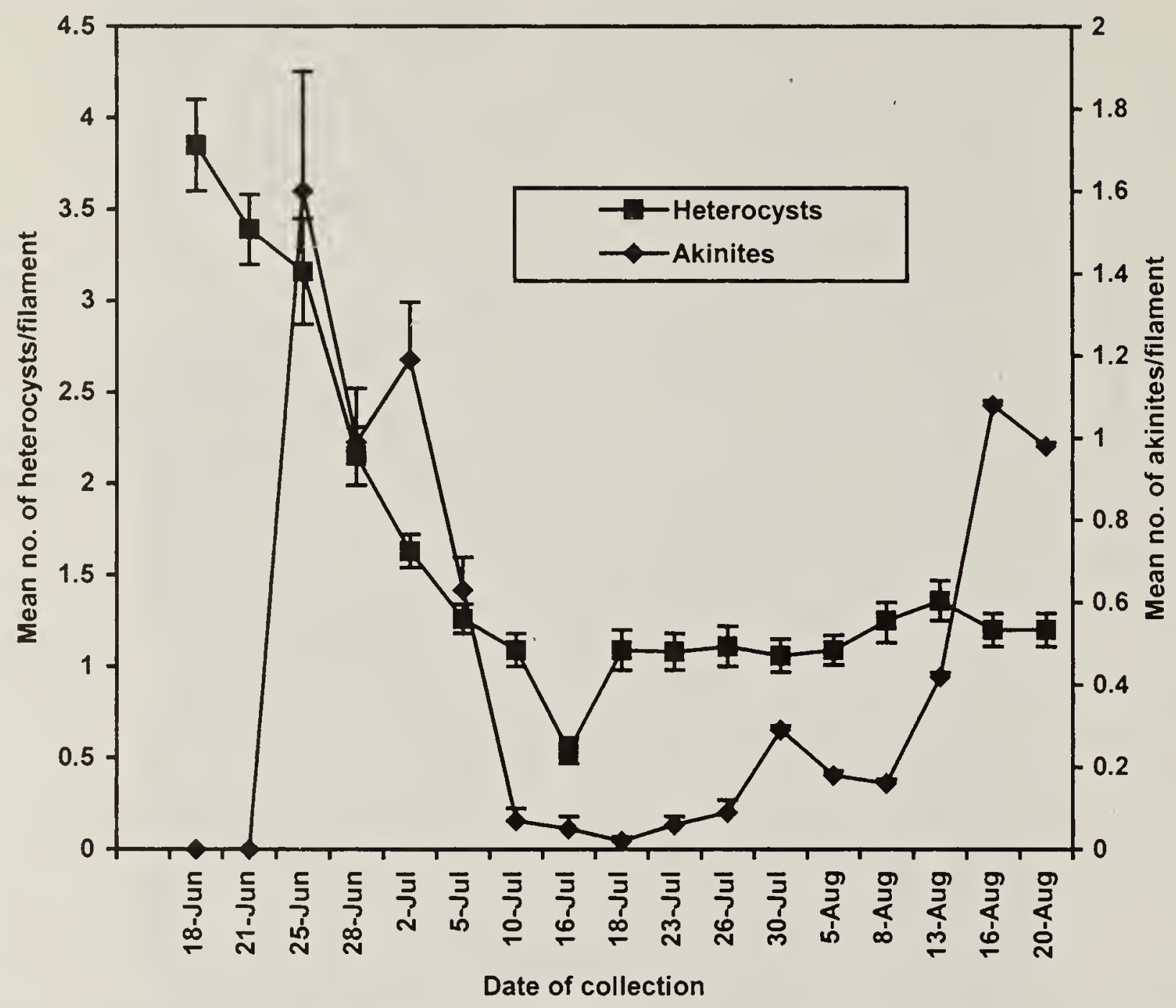

Figure 3. A comparison of changes in the number of cell types in filaments of Anabaena flos-aquae in the Wascana Lake during the growing season. (Standard errors are indicated).

repository of abundant storage substances (Fig. 1D). The akinete is important in the asexual reproduction of the species. It can overwinter and germinate in spring to form a filament.

Both heterocysts and akinetes are produced throughout the growing season. Abundant heterocysts are produced early in the season and their number declines considerably by about mid-July (Fig. 3). Subsequently, there is a slight increase and the number stays about the same during the rest of the summer (Fig. 3). The akinete cells do not increase until June (Fig. 3). Eventually, they decline in number and continue to be about the same until the first week of August and later greatly increase (Fig. 3). In the final stages the vegetative cells of filaments disintegrate freeing akinites which sink to the bottom of the lake.

Wascana Lake, because of its location, is highly visible to residents of Regina. It is also readily accessible to many schools and the University of Regina, offering an opportunity for environmental and biological investigations at all levels. Its waters are teaming with abundant microorganisms, including algae and invertebrates. Rather than considering Wascana Lake a eutrophic "duckpond" it can be a unique educational opportunity waiting at our doorstep to be investigated. Some papers relating to Wascana Lake have been published. ${ }^{10-12}$

In the Fall of 1997 and 1998, the city 
of Regina drained off completely a part of Wascana Lake to monitor the aftereffects on the flora and fauna there. It would be extremely interesting to see the changes in that part of the lake in the coming years!

\section{References}

1.CARR, N.G. and B.A. WHITTON. 1973. The biology of the blue-green algae. University of California Press, Berkeley.

2. and 1983. The biology of cyanobacteria. University of California Press, Berkeley.

3.FOGG, G.E. 1971. Nitrogen fixation in lakes. Plant and Soil. Special Volume 1971. Pp. 393-401.

4.FOGG, G.E., W.D.P. STEWART, P. FAY and A.E. WALSBY. 1973. The Bluegreen algae. Academic Press, New York.

5.HAMMER, U.T. 1964. The succession of bloom - species of blue-green algae and some causal factors. Verh. Internat. Verein. Limnol. 15:829-836.

6. 1969. Blue-green algal blooms in Saskatchewan lakes. Verh. Internat. Verein. Limnol. 17:116-125.

7. 1995. Saline lake limnology Saskatchewan style. Blue Jay 53:215226.

8.HOLMS, R. 1996. Life Unlimited. New Scientist 149:26-29.

9.ODUM, P. 1971. Fundamentals of ecology. W.B. Saunders Co., New York.

10. RAJU, M.V.S. 1970. Red-tide in Wascana Lake. Blue Jay 28:50-53.
11. RAJU, M.V.S., D. YOUNG and J.E. HINES. 1971. A check-list of algae in Wascana Lake. Blue Jay 29:215-216.

12. RAJU, M.V.S., J.E. HINES and L.A. PENDLEBURY. Algal blooms. Blue Jay 30:56-61.

13. RAWSON, D.S. 1956. Algal indicators of trophic lake types. Limnol. Oceanogr. 1:18-25.

14. SCHOPF, J.W. 1970. Precambrian microorganisms and evolutionary events prior to the origin of vascular plants. Biol. Rev. 45:319-352.

15. SCHOFF, J.W. and M.R. WALTER. 1982. Origin and early evolution of Cyanobacteria: the geological evidence. Pp. 543-564. In N.G. Carr and B.A. Whitton (eds.). The Biology of Cyanobacteria. University of California, Berkeley.

16. STEWART, W.D.P. 1971. Physiological studies on nitrogen-fixing blue-green algae. Plant and soil, Special volume, pp. 371-391.

17. VALLENTYNE, J.R. 1974. The algal bowl - Lakes and man. Department of the Environment Fisheries and Marine Service, Ottawa, Canada.

18. VALLENTYNE, J.R. 1972. Freshwater supplies and pollution: effects of the demophoric explosion on water and man. Pp. 181-211 In N. Pollunin (ed.). The environmental future. Macmillan, New York. 